\section{Differential Responses of Nutrients to Heat Stress in Warm-season and Cool-season Turfgrasses}

\author{
Hua Shen, Hongmei Du, and Zhaolong Wang \\ Center of Turfgrass Science, Shanghai Jiao Tong University, Shanghai, \\ P.R. China
}

\author{
Bingru Huang ${ }^{1}$ \\ Department of Plant Biology and Pathology, Rutgers University, Room 301 \\ Foran Hall, 59 Dudley Road, New Brunswick, NJ 08901
}

Additional index words. bermudagrass, high temperature, kentucky bluegrass, nutrient

\begin{abstract}
The objective of this study was to compare differential nutrient responses to heat stress in relation to heat tolerance for warm-season $\left(C_{4}\right)$ common bermudagrass [Cynodon dactylon (L.) Pers.] and cool-season $\left(\mathrm{C}_{3}\right)$ kentucky bluegrass (Poa pratensis $\mathrm{L}$.). Both species were exposed to two temperature regimes in growth chambers: optimal day/night temperature conditions $\left(24 / 20{ }^{\circ} \mathrm{C}\right.$ for kentucky bluegrass and $34 / 30{ }^{\circ} \mathrm{C}$ for bermudagrass) or heat stress $\left(10^{\circ} \mathrm{C}\right.$ above the respective optimal temperature for each species). Heat injury in leaves was evaluated and the concentrations of several major macronutrients [nitrogen $(N)$, phosphorus $(P)$, potassium $(K)$, calcium $(C a)$, and magnesium $(\mathrm{Mg})]$ in both grass species were measured at $0,7,14,21$, and 28 days of treatment. Heat stress reduced leaf photochemical efficiency and cellular membrane stability in both species, but bermudagrass leaves exhibited less damage in these parameters than kentucky bluegrass. Heat stress caused a significant decline in $\mathbf{N}, \mathbf{P}$, and $K$ concentration, beginning at 7 days in kentucky bluegrass, but had no significant effects on $N, P$, and $K$ concentration in bermudagrass during the 28-day treatment period. The concentration of $\mathrm{Ca}$ and $\mathrm{Mg}$ increased under heat stress in both kentucky bluegrass and bermudagrass, but there were no significant differences between the species under optimal or high-temperature conditions, suggesting they were not involved in heat responses in either species. The differential responses of $N$, P, and $K$ to heat stress could at least partially account for the differences in heat tolerance between the two species and demonstrate the importance of sufficient $N, P$, and $K$ in turfgrass adaptation to heat stress.
\end{abstract}

High temperature is a major factor limiting the growth of turfgrasses during summer in many areas, especially in cool-season species, because cool-season grasses grow most actively within the temperature range of 16 to $24{ }^{\circ} \mathrm{C}$ and warm-season grasses have a temperature optimum of 27 to $35{ }^{\circ} \mathrm{C}$ (DiPaola and Beard, 1992). Physiological and metabolic factors, including photosynthesis, hormone metabolism, water relations as well as nutrient metabolism, can be attributed to the variations in heat tolerance between warm-season and cool-season plant species (DiPaola and Beard, 1992; Fry and

Received for publication 22 June 2009. Accepted for publication 10 Aug. 2009.

We thank Emily Merewitz, Yan Xu, and Chenping $\mathrm{Xu}$ at Rutgers University for reviewing the manuscript and Longxing $\mathrm{Hu}$ for assistance in data analysis and graphing. We also express our sincere thanks to the Chinese Ministry of Education for awarding the Chang Jiang Fellowship grant to Dr. Bingru Huang who, in turn, provided partial funding for this collaborative research project between Shanghai Jiao Tong University and Rutgers University.

${ }^{1}$ To whom reprint requests should be addressed; e-mail huang@aesop.rutgers.edu.
Huang, 2004). Nutrient deficiency under heat stress has been observed in various coolseason turfgrass species, which may largely contribute to growth inhibition $(\mathrm{Fu}$ and Huang, 2003; Liu, 2008; Liu and Huang, 2005). Nutrient use efficiency for most coolseason turfgrass species is reduced by heat stress mainly resulting from reduced uptake (Liu, 2008). The adverse effects of high temperatures on shoot growth in creeping bentgrass (Agrostis stolonifera L.) have been associated with decreased nutrient uptake of root systems resulting from reduced root viability under heat stress (Huang and $\mathrm{Xu}$, 2000; Liu and Huang, 2005).

A majority of previous research addressing heat stress effects on nutrient accumulation and uptake focuses on cool-season grass species; information on the comparative responses of nutrients to heat stress between warm-season and cool-season species is lacking. Most notably, how nutrient accumulation is associated with differences in heat tolerance and specifically heat-induced damage in leaves between warm-season and coolseason grass species is not well documented. In addition, different nutrient elements may differ in their sensitivity to heat stress, which could affect plant responses to heat stress in different species, as is the case in creeping bentgrass (Liu and Huang, 2005). To better understand the mechanism underlying turfgrass heat tolerance associated with nutrient accumulation, the study was designed to compare differential nutrient responses to heat stress in relation to heat tolerance for warm-season $\left(\mathrm{C}_{4}\right)$ common bermudagrass [Cynodon dactylon (L.) Pers.] and cool-season $\left(\mathrm{C}_{3}\right)$ kentucky bluegrass (Poa pratensis L.). The comparative analysis may reveal major nutrient elements involved in plant tolerance to heat stress. Bermudagrass is a commonly used turfgrass in warm climatic regions, whereas kentucky bluegrass is widely used in cool climatic regions (Fry and Huang, 2004). Both species were subjected to supraoptimal air temperatures $\left(10^{\circ} \mathrm{C}\right.$ above the optimal temperature range). Heat tolerance was evaluated using two commonly used stress indicators, leaf photochemical efficiency and cellular membrane stability (Marcum, 1998; Rachmilevitch et al., 2006). The concentration of macronutrient elements was measured to determine major nutrient elements involved in differential heat responses for bermudagrass and kentucky bluegrass.

\section{Materials and Methods}

\section{Plant materials}

Sods of 2-year-old kentucky bluegrass (cv. Midnight) and bermudagrass (cv. Tifway) were collected from field plots at the Turfgrass Research Farm, Shanghai Jiaotong University, Shanghai, China, and the study was conducted using greenhouse and growth chambers on this campus. The grasses were grown in plastic pots $(20 \mathrm{~cm}$ in diameter, 15 $\mathrm{cm}$ in depth) filled with a silt loam soil (fineloamy, mixed mesic Typic Hapludult) in the greenhouse for $30 \mathrm{~d}$. Plants were then transferred to growth chambers (Wuhan Ruihua Instrument \& Equipment Co., Ltd., Wuhan, China) with a temperature of $24 / 20^{\circ} \mathrm{C}$ (day/ night) for kentucky bluegrass and $34 / 30{ }^{\circ} \mathrm{C}$ (day/night) for bermudagrass, a 14-h photoperiod, and a photosynthetically active radiation $(P A R)$ of $600 \mu \mathrm{mol} \cdot \mathrm{m}^{-2} \cdot \mathrm{s}^{-1}$ at the canopy level. Turf was mowed every $3 \mathrm{~d}$ to maintain a 4-cm canopy height during the entire experimental period (before and during heat stress). Plants were watered every other day until water drained from the bottom of the pot and fertilized every 2 weeks for three times before heat treatment imposition with a controlled-release fertilizer $(15 \mathrm{~N}-6.5 \mathrm{P}-$ $8.3 \mathrm{~K})$ at a total amount of $57 \mathrm{~kg} \cdot \mathrm{ha}^{-1}$ nitrogen, including magnesium $(2.00 \%)$, sulfur $(4.00 \%)$, boron $(0.02 \%)$, copper $(0.05 \%)$, iron $(0.20 \%$ water soluble and $0.20 \%$ chelated iron), manganese $(0.10 \%)$, molybdenum $(0.02 \%)$, and zinc $(0.05 \%)$.

\section{Temperature treatments}

Plants of each species were subjected to the following two treatments for $30 \mathrm{~d}$ : 1) control: plants were maintained at the respective optimal day/night temperature for each species $\left(24 / 20{ }^{\circ} \mathrm{C}\right.$ for bluegrass and 
$34 / 30{ }^{\circ} \mathrm{C}$ for bermudagrass) and watered daily until drainage occurred from the bottom of the pot; and 2) heat stress: plants were exposed to supraoptimal day/night temperatures of $10{ }^{\circ} \mathrm{C}$ above the optimum for each species $\left(34 / 30{ }^{\circ} \mathrm{C}\right.$ for bluegrass and $44 / 40{ }^{\circ} \mathrm{C}$ for bermudagrass) while irrigated in the same manner as for the control treatment.

The three temperature regimes (day/night $24 / 20,34 / 30$, or $44 / 40^{\circ} \mathrm{C}$ ) were conducted in three chambers simultaneously. Each chamber set at a temperature regime contained three pots for each grass species. The growth chamber set at $24 / 20{ }^{\circ} \mathrm{C}$ contained the bluegrass control treatment; the chamber set at $34 / 30{ }^{\circ} \mathrm{C}$ contained the bermudagrass control treatment and the bluegrass heat treatment; and the chamber set at $44 / 40{ }^{\circ} \mathrm{C}$ contained the bermudagrass heat treatment. The three temperature treatments were repeated three times at 30-d intervals. The temperature in each chamber was randomly reassigned to ensure that each temperature treatment for each turfgrass species was repeated in three different growth chambers and to minimize effects of environmental variations between chambers. All growth chambers had a 14-h photoperiod, PAR of $600 \mu \mathrm{mol} \cdot \mathrm{m}^{-2} \cdot \mathrm{s}^{-1}$, and $70 \%$ to $80 \%$ relative humidity regulated by a humidifier (Wuhan Ruihua Instrument \& Equipment Co., Ltd.).

\section{Measurements}

Heat tolerance was evaluated as leaf photochemical efficiency and cellular membrane stability. Both parameters are widely used for heat tolerance evaluation (Marcum, 1998; Rachmilevitch et al., 2006). Leaf photochemical efficiency was determined by measuring chlorophyll fluorescence, the ratio of variable fluorescence to maximum fluorescence $(\mathrm{Fv} / \mathrm{Fm})$, with a leaf photochemical efficiency analyzer (OS 1FL; OptiSciences, Hudson, NH). Leaves were exposed to darkness for $30 \mathrm{~min}$ before readings were taken to allow dark adaptation of leaves. Cellular membrane stability was estimated by measuring electrolyte leakage (EL) (Blum and Ebercon, 1981). For EL analysis, first and second fully expanded leaves with fresh weight of $0.3 \mathrm{~g}$ per pot were excised and cut into $1-\mathrm{cm}$ segments. Leaf segments were rinsed three times with distilled water and placed into $50-\mathrm{mL}$ vials containing $20 \mathrm{~mL}$ distilled water. The initial conductivity $\left(\mathrm{C}_{\mathrm{i}}\right)$ of the bathing solution after shaking for $24 \mathrm{~h}$ was measured with a conductivity meter (DDS-11C; Analytical Equipment Co., Tianjin, China). Leaves were then killed in an autoclave at $121{ }^{\circ} \mathrm{C}$ for $30 \mathrm{~min}$ and placed on a shaker for $24 \mathrm{~h}$ before measuring the final conductivity $\left(\mathrm{C}_{\max }\right)$ of the bathing solution. The EL was calculated as $\left(\mathrm{C}_{\mathrm{i}} / \mathrm{C}_{\max }\right) \times 100$.

The concentration of nitrogen $(\mathrm{N})$ phosphorus $(\mathrm{P})$ potassium $(\mathrm{K})$, calcium $(\mathrm{Ca})$, and magnesium $(\mathrm{Mg})$ in leaf tissues was analyzed. Five grams of fresh leaves were sampled from each pot and immediately frozen in liquid nitrogen. Leaf tissues were oven-dried at $100{ }^{\circ} \mathrm{C}$ first and then at $85{ }^{\circ} \mathrm{C}$
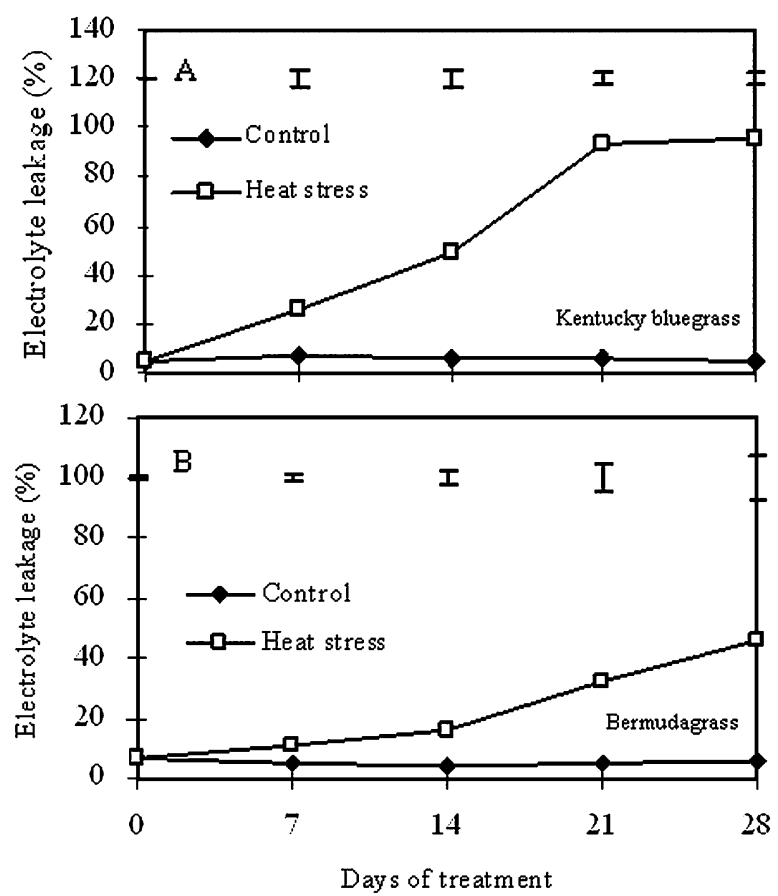

Fig. 1. Cellular membrane stability, expressed as percentage of electrolyte leakage (EL), in kentucky bluegrass (A) and bermudagrass (B) under optimal temperature (control) and heat stress. The datum at a given day of treatment is the average of three replicates for each treatment. Vertical bars represent least significant difference (LSD) $(P=0.05)$ values for treatment comparison at a given day of treatment. The LSD values for the comparison between kentucky bluegrass and bermudagrass were 0.94, 13.19, $14.13,21.01$, and 26.14 at $0,7,14,21$, and $28 \mathrm{~d}$, respectively, of heat stress.
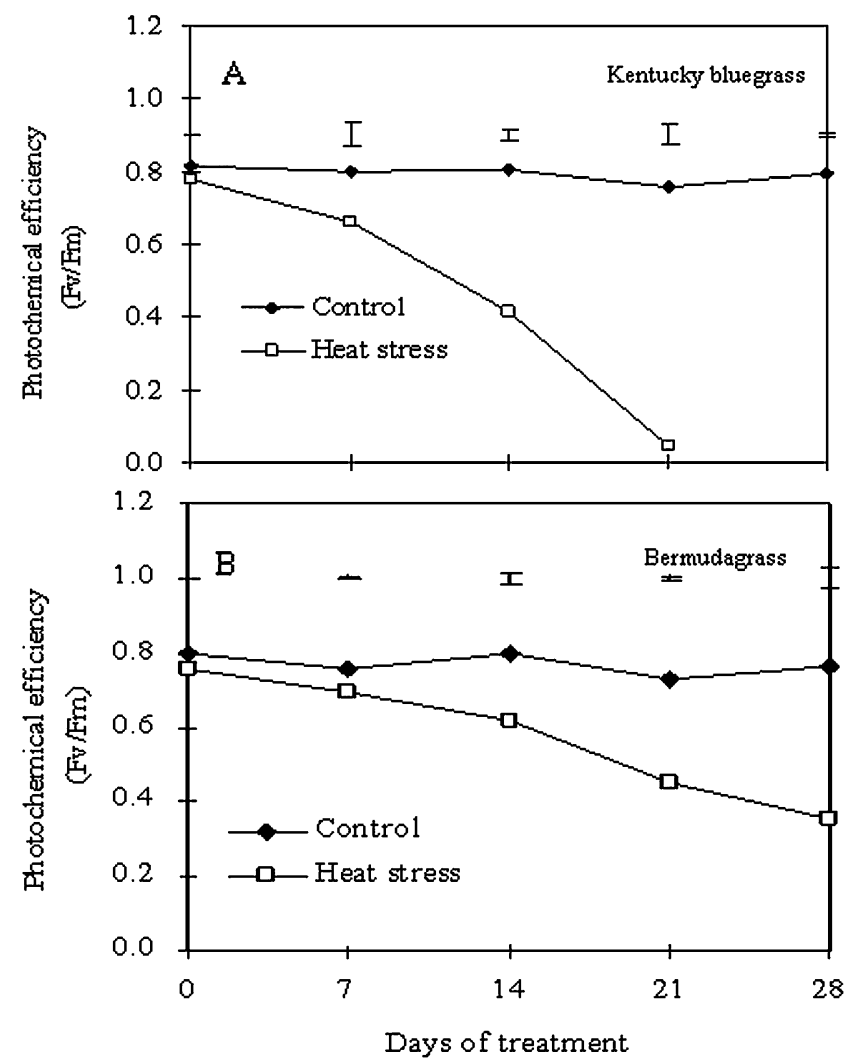

Fig. 2. Leaf photochemical efficiency $(\mathrm{Fv} / \mathrm{Fm})$ in kentucky bluegrass $(\mathbf{A})$ and bermudagrass $(\mathbf{B})$ under optimal temperature (control) and heat stress. The datum at a given day of treatment is the average of three replicates for each treatment. Vertical bars represent least significant difference (LSD) $(P=0.05)$ values for treatment comparison at a given day of treatment. The LSD values for the comparison between kentucky bluegrass and bermudagrass were $0.004,0.02,0.05,0.08$, and 0.16 at $0,7,14,21$, and $28 \mathrm{~d}$, respectively, of heat stress. 


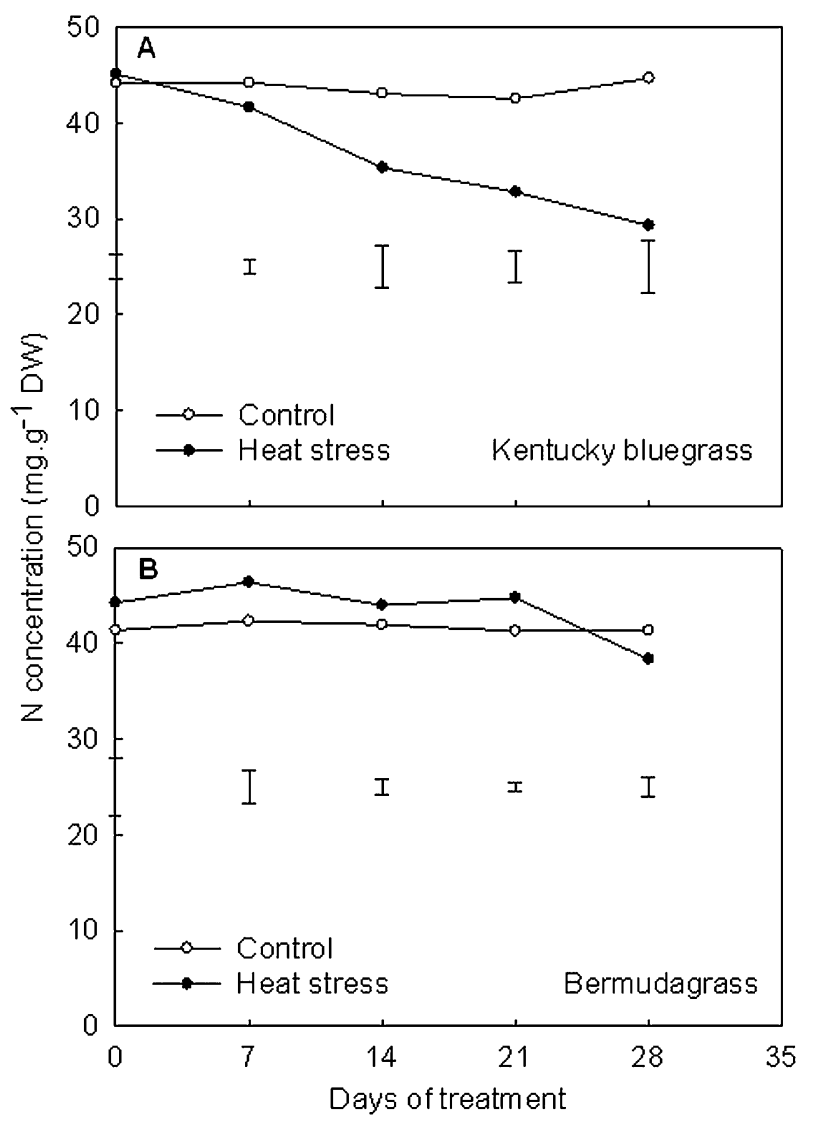

Fig. 3. Nitrogen $(\mathrm{N})$ concentration in kentucky bluegrass (A) and bermudagrass (B) under optimal temperature (control) and heat stress. The datum at a given day of treatment is the average of three replicates for each treatment. Vertical bars represent least significant difference (LSD) $(P=0.05)$ values for treatment comparison at a given day of treatment. The LSD values for the comparison between kentucky bluegrass and bermudagrass were $0.22,0.3030 .33,0.31$ and 0.31 at 0 , $7,14,21$, and $28 \mathrm{~d}$, respectively, of heat stress.

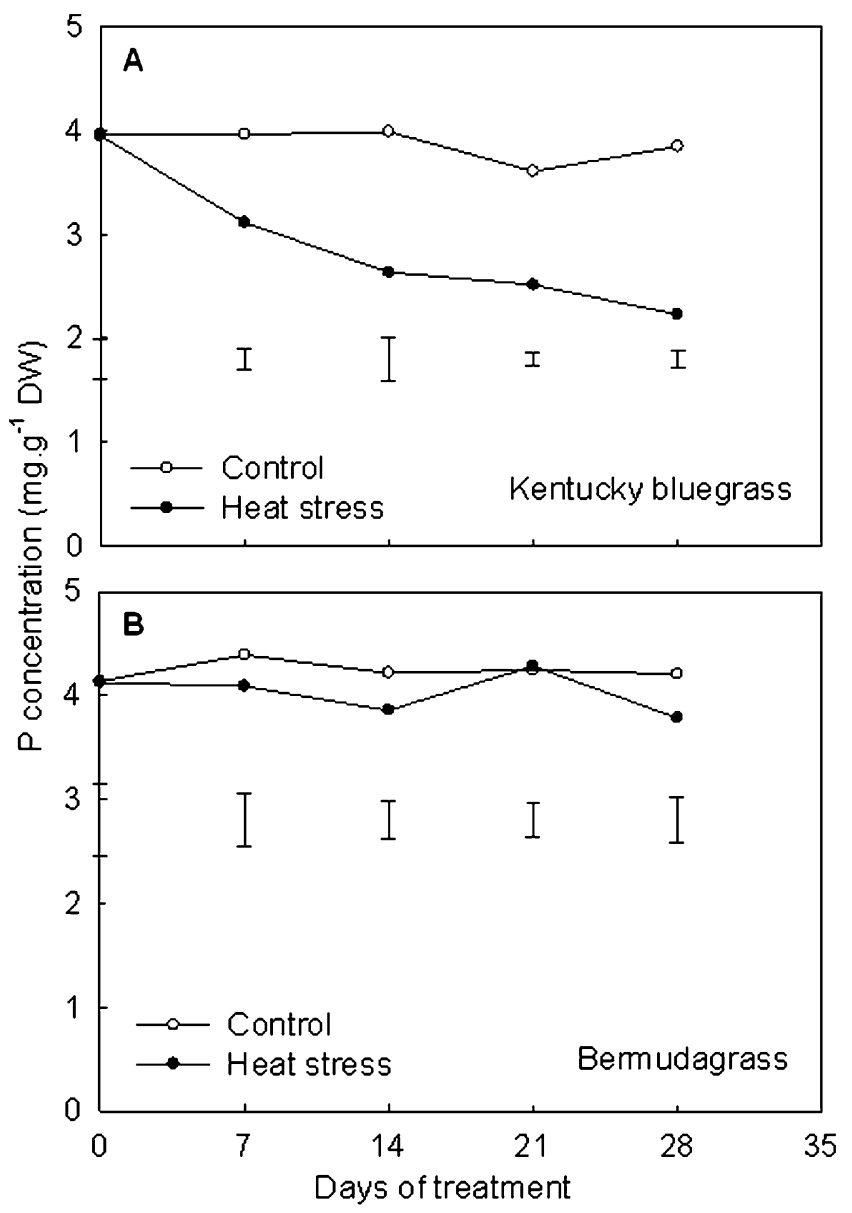

Fig. 4. Phosphorus (P) concentration in kentucky bluegrass (A) and bermudagrass (B) under optimal temperature (control) and heat stress. The datum at a given day of treatment is the average of three replicates for each treatment. Vertical represent are least significant difference (LSD) $(P=0.05)$ values for treatment comparison at a given day of treatment. The LSD values for the comparison between kentucky bluegrass and bermudagrass were $0.05,0.02,0.05,0.02$, and 0.04 at $0,7,14,21$, and $28 \mathrm{~d}$, respectively, of heat stress. for $72 \mathrm{~h}$ until reaching constant weight. After the samples were ground into fine powder with a mortar and pestle, $\mathrm{N}$ concentration was analyzed using an element analyzer (Vario EL III; Element, Elementar Analysensysteme, Germany). The concentrations of $\mathrm{P}, \mathrm{K}, \mathrm{Ca}$, and $\mathrm{Mg}$ in the solution were analyzed using an inductively coupled plasma spectrophotometer (IRIS Advantage 100; Thermo Electron, Waltham, MA) (Jiang and Huang, 2001). To determine the concentration of $\mathrm{P}, \mathrm{K}, \mathrm{Ca}$, and $\mathrm{Mg}$, dry powder was placed into a beaker followed by adding $10 \mathrm{~mL}$ nitric acid and then heated to $100{ }^{\circ} \mathrm{C}$ for 2 to $3 \mathrm{~h}$ for digestion under a ventilation hood. The final volume of the solution was brought to $100 \mathrm{~mL}$ in a capacitor. After the solution cooled to room temperature, it was filtered until clear.

\section{Design and statistical analysis}

Experimental design and statistical analysis. Species and treatments were arranged as a randomized block design. The analysis of variance procedure in Statistical Analysis Systems (SAS) (SAS 8.1; SAS Institute Inc., Cary, NC) was used to test for treatment effects and species comparisons. Means were separated using Fisher's protected least significance difference test at $P=0.05$.

\section{Results and Discussion}

Heat stress caused significant increases in EL in leaves of kentucky bluegrass with EL reaching $95 \%$ by $28 \mathrm{~d}$ of treatment, whereas EL also increased in bermudagrass during heat stress, but only to $46 \%$ by $28 \mathrm{~d}$ (Fig. 1 ). In addition, leaf $\mathrm{Fv} / \mathrm{Fm}$ declined rapidly during heat stress in kentucky bluegrass and dropped close to zero by $21 \mathrm{~d}$ of treatment, whereas $\mathrm{Fv} / \mathrm{Fm}$ declined to a lesser extent in bermudagrass than in kentucky bluegrass with $\mathrm{Fv} / \mathrm{Fm}$ maintained at $0.4 \times 28 \mathrm{~d}$ of treatment (Fig. 2). These results indicated that bermudagrass leaves had more thermostable membranes and were able to maintain more efficient photochemical reactions or photosynthesis than kentucky bluegrass. It is well recognized that many physiological and metabolic factors may account for the differences in heat tolerance between coolseason and warm-season grass species
(DiPaola and Beard, 1992; Fry and Huang, 2004). This study suggested that the differences in physiological damages between the two species could be at least partially related to the differential responses of nutrient accumulation, as discussed subsequently.

Nitrogen plays a pivotal role in many critical functions in the plant such as photosynthesis, chlorophyll synthesis and protein synthesis, which control plant adaptation to heat stress (Cao et al., 1999; Evans, 1983). N availability may be involved in plant adaptation to heat stress through the regulation of protein synthesis (Heckathorn et al., 1996). In this study, $\mathrm{N}$ concentration in leaves of kentucky bluegrass decreased during heat stress compared with the control plants at $24{ }^{\circ} \mathrm{C}$ (Fig. 3A). By $28 \mathrm{~d}$ of treatment, $\mathrm{N}$ concentration of heat-stressed plants decreased by $30 \%$, compared with the control, and was below the sufficient range in turfgrass tissues (28 to $35 \mathrm{mg} \cdot \mathrm{g}^{-1}$ dry weight) (Turner and Hummel, 1992). The N concentration of bermudagrass did not decline under heat stress and was above the sufficient range previously noted (Fig. 3B). No significant difference in $\mathrm{N}$ concentration was detected 


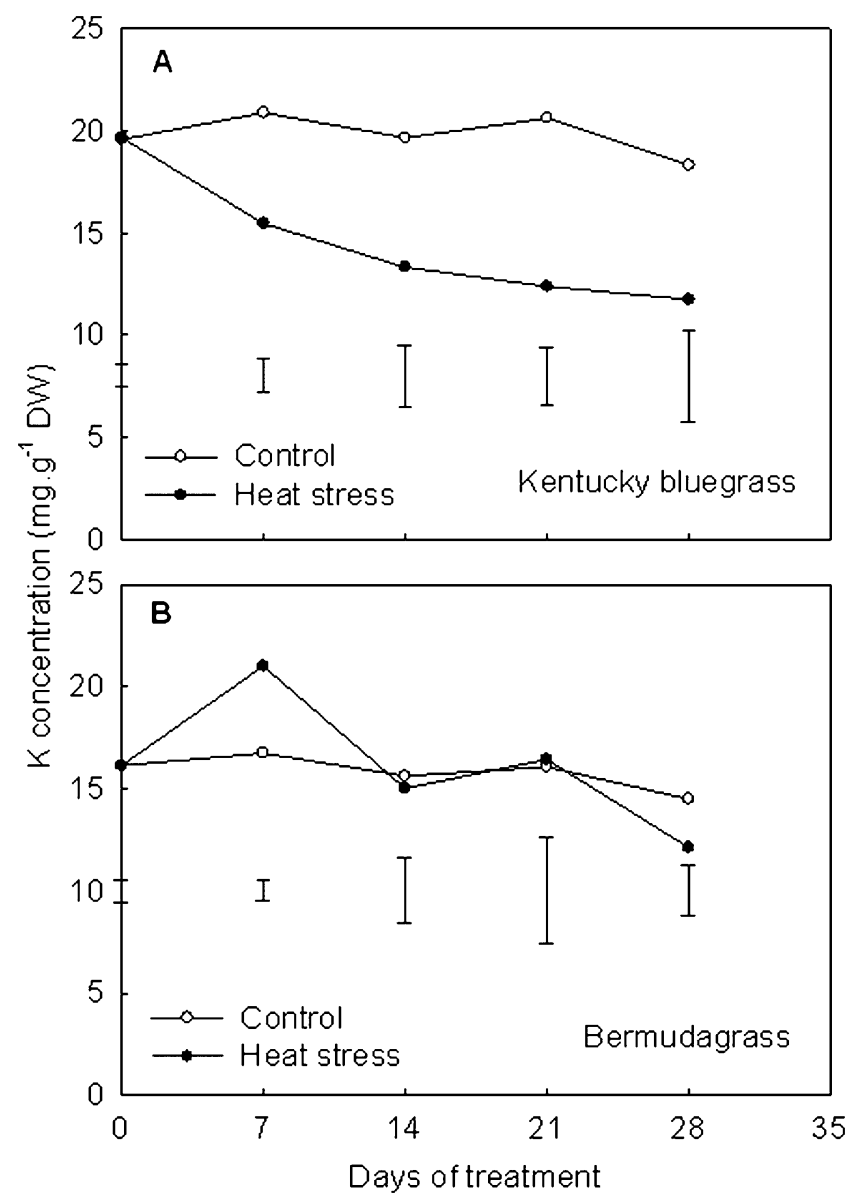

Fig. 5. Potassium (K) concentration in kentucky bluegrass (A) and bermudagrass (B) under optimal temperature (control) and heat stress. The datum at a given day of treatment is the average of three replicates for each treatment. Vertical bars represent least significant difference (LSD) $(P=0.05)$ values for treatment comparison at a given day of treatment. The LSD values for the comparison between kentucky bluegrass and bermudagrass were $0.17,0.11,0.33,0.51$, and 0.28 at 0 , $7,14,21$, and $28 \mathrm{~d}$, respectively, of heat stress

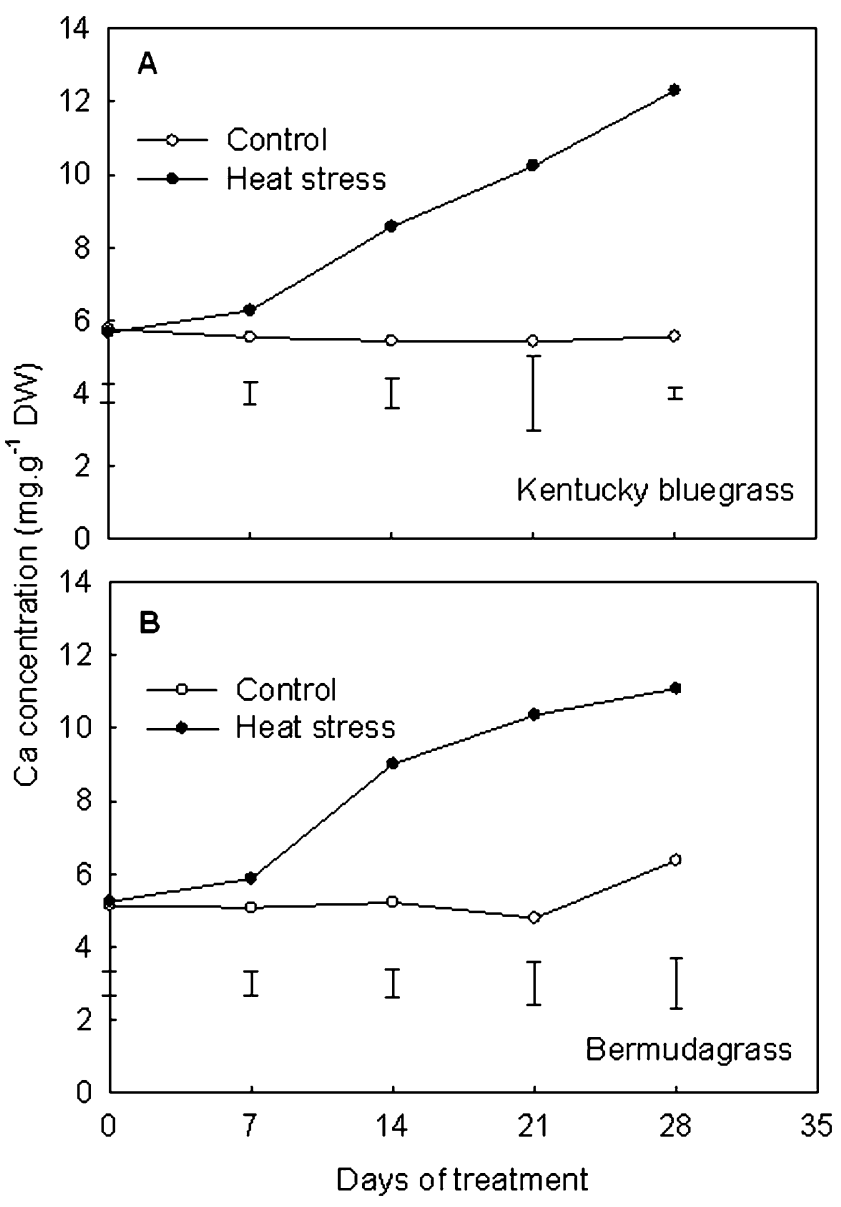

Fig. 6. Calcium (Ca) concentration in kentucky bluegrass (A) and bermudagrass (B) under optimal temperature (control) and heat stress. The datum at a given day of treatment is the average of three replicates for each treatment. Vertical bars represent least significant difference (LSD) $(P=0.05)$ values for treatment comparison at a given day of treatment. The LSD values for the comparison between kentucky bluegrass and bermudagrass were $0.09,0.05,0.08,0.19$, and 0.08 at $0,7,14,21$, and $28 \mathrm{~d}$, respectively, of heat stress. between bermudagrass plants exposed to heat stress and those growing under the optimal temperature. In addition, $\mathrm{N}$ concentration was significantly higher in bermudagrass than in kentucky bluegrass under heat stress, whereas no significant difference in $\mathrm{N}$ concentration was observed between the two species under optimal temperatures (Fig. 3A versus Fig. 3B). These results suggest that bermudagrass was better capable of maintaining $\mathrm{N}$ uptake and metabolism, which could be associated with lesser extent of leaf senescence compared with kentucky bluegrass, as described previously. Foliar application of $\mathrm{N}$ has been found to improve heat tolerance of cool-season turfgrass species such as creeping bentgrass associated with the increase in chlorophyll synthesis and antioxidant enzyme activities (Fu and Huang, 2003). The positive effects of foliar-applied $\mathrm{N}$ on heat tolerance in turfgrass could be related to the increase or maintenance of synthesis of nitrogenous compounds such as amino acids and proteins, which otherwise are degraded under heat stress during leaf senescence.
Phosphorus is involved in several key functions related to plant adaptation to heat stress such as energy transfer, membrane stability, and photosynthesis (Ticconi and Abel, 2004; White and Hammond, 2008). P concentration in kentucky bluegrass decreased significantly below the control level from 7 to $28 \mathrm{~d}$ of treatment (Fig. 4A). In addition, $\mathrm{P}$ concentration in heat-stressed kentucky bluegrass decreased by $42 \%$ by 28 $\mathrm{d}$, which was below the sufficient ranges of 1 to $4 \mathrm{mg} \cdot \mathrm{g}^{-1}$ dry weight (Turner and Hummel, 1992). The $P$ concentration in bermudagrass was not significantly affected during $28 \mathrm{~d}$ of heat stress and remained above the sufficient range during heat stress (Fig. 4B). Adequate $P$ levels in heat-stressed bermudagrass may increase the probability of plant survival by regulating various physiological processes such as those previously discussed. Low $\mathrm{P}$ availability aggravated the membrane lipid peroxidation in rice (Oryza sativa L.) leaves, and it was more severe in low-P-sensitive cultivars (Pan and Liu, 2003).

Leaf $\mathrm{K}$ concentration exhibited the same decline pattern as $\mathrm{N}$ and $\mathrm{P}$ in response to heat stress for both grass species (Fig. 5A). A 26\% decline in $\mathrm{K}$ concentration was observed in kentucky bluegrass at $7 \mathrm{~d}$ of treatment, and at $28 \mathrm{~d}$, it decreased by $36 \%$. A significant difference was not observed between the control treatment and the heat-stressed bermudagrass plants during most of the treatment period, except at $7 \mathrm{~d}$ (Fig. 5B). Potassium is involved in various physiological processes, including the regulation of stomatal aperture (Humble and Raschke, 1971), which controls the transpirational cooling mechanisms of plant adaptation to heat stress (Bonos and Murphy, 1999). Decreased $\mathrm{K}$ concentration results in stomatal closure and thus reduces the plant's ability to cool under high-temperature stress (Salisbury and Ross, 1978). Therefore, the maintenance of $\mathrm{K}$ accumulation in bermudagrass could facilitate stomatal opening for more efficient transpirational cooling. However, a direct correlation between $\mathrm{K}$ concentration and stomatal regulation has not been reported in turfgrasses. Increased $\mathrm{K}$ fertility improved heat tolerance in kentucky bluegrass (Pellett and Roberts, 1963) and creeping bentgrass 


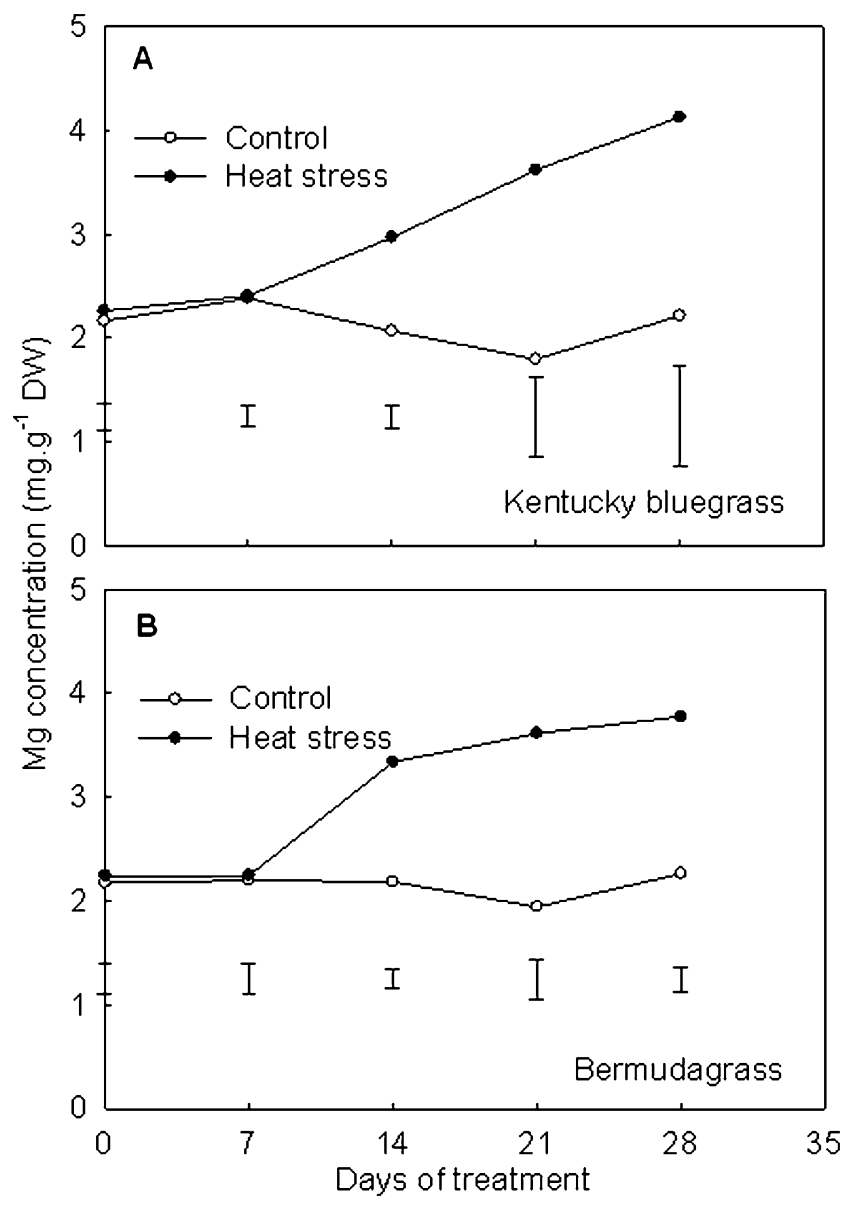

Fig. 7. Magnesium (Mg) concentration in kentucky bluegrass (A) and bermudagrass (B) under optimal temperature (control) and heat stress. The datum at a given day of treatment is the average of three replicates for each treatment. Vertical bars represent least significant difference (LSD) $(P=0.05)$ values for treatment comparison at a given day of treatment. The LSD values for the comparison between kentucky bluegrass and bermudagrass were $0.02,0.01,0.03,0.07$, and 0.02 at $0,7,14,21$, and $28 \mathrm{~d}$, respectively, of heat stress.

(Fu and Huang, 2003). Foliar application of $\mathrm{KH}_{2} \mathrm{PO}_{4}$ was found to delay leaf senescence and increase grain yield during hot, dry summers in winter wheat (Triticum aestivum L.) (Sherchand and Paulsen, 1985).

In contrast to the responses of $\mathrm{N}, \mathrm{P}$, and $\mathrm{K}$ to heat stress, $\mathrm{Ca}$ (Fig. 6A-B) and $\mathrm{Mg}$ (Fig. 7A-B) concentration increased to significantly higher levels in both species during heat stress compared with their respective control treatments. No significant differences in $\mathrm{Mg}$ and $\mathrm{Ca}$ concentration were detected between the two grass species under the control temperature or heat stress. Magnesium is a major component of the chlorophyll molecule and plays an important role in the modulation of many cellular enzymes and the aggregation of ribosomes (Romani and Scarpa, 2000; Shaul, 2002; Silman et al., 1965). Sufficient accumulation of $\mathrm{Mg}$ in leaf tissues under heat stress indicates that $\mathrm{Mg}$ may not be involved in heat-induced leaf senescence in either grass species. High temperature has been reported to increase uptake of $\mathrm{Ca}$ in different plant species such as maize (Zea mays L.) (Lal, 1974) and pear (Pyrus communis L.) (Klein and Ferguson, 1987). The enhanced $\mathrm{Ca}$ uptake has been associated with the increases in plasma membrane permeability in cells exposed to high temperatures (Klein and Ferguson, 1987). Larkindale and Knight (2002) reported calcium alleviates heat-induced oxidative damage in Arabidopsis. Maize seeds pretreatment with a $\mathrm{CaCl}_{2}$ solution have much higher calcium and calmodulin levels and also are more tolerant to high temperature in the seedling stage (Gong et al., 1997). However, excessive $\mathrm{Ca}^{2+}$ released into the cytosol may be cytotoxic (Wang and Li, 1999). Nevertheless, the high levels of $\mathrm{Mg}$ and $\mathrm{Ca}$ in both species under heat stress suggests that there may be elevated levels of both elements in plants subjected to heat stress.

In summary, heat stress caused less damage in leaf membrane and photochemical reactions in bermudagrass than in kentucky bluegrass. The differential physiological responses corresponded with differential changes in nutrient accumulation. The lack of differences in $\mathrm{Mg}$ and $\mathrm{Ca}$ concentration under heat stress between kentucky bluegrass and bermudagrass indicated that these two nutrients could not account for the differences in heat responses between the warmseason and cool-season grass species. The significant decline in $\mathrm{N}, \mathrm{P}$, and $\mathrm{K}$ during heat stress for kentucky bluegrass suggests that uptake and metabolism of these three macronutrients were impeded by heat stress in coolseason turfgrass. The unaffected N, P, and K levels in bermudagrass during 28-d heat stress suggests that adequate $\mathrm{N}, \mathrm{P}$, and $\mathrm{K}$ uptake and accumulation play a critical role in plant survival during heat stress in warmseason grass species; therefore, providing adequate fertility, particularly $\mathrm{N}, \mathrm{P}$, and $\mathrm{K}$ may alleviate heat stress damages in coolseason turfgrasses.

\section{Literature Cited}

Blum, A. and A. Ebercon. 1981. Cell membrane stability as a measure of drought and heat tolerance in wheat. Crop Sci. 21:43-47.

Bonos, S.A. and J.A. Murphy. 1999. Growth responses and performance of kentucky bluegrass under summer stress. Crop Sci. 39:770774.

Cao, C., S. Li, and F. Miao. 1999. The research situation about effects of nitrogen on certain physiological and biochemical process in plants. J. Northwest A\&F University (Natural Science Edition) 27:96-100.

DiPaola, J.M. and J.B. Beard. 1992. Physiological effects of temperature stress, p. 231-262. In: Waddington, D.V., R.N. Carrow, and R.C. Shearman (eds.). Turfgrass. Agronomy Monograph 32. Agronomy Society of America, Madison, WI.

Evans, J.R. 1983. Nitrogen and photosynthesis in the flag leaf of wheat (Triticum aestivum L.). Plant Physiol. 72:297-302.

Fry, J. and B. Huang. 2004. Applied turfgrass science and physiology. Wiley, Hoboken, NJ.

$\mathrm{Fu}$, J. and B. Huang. 2003. Effects of foliar application of nutrients on heat tolerance of creeping bentgrass. J. Plant Nutr. 26:81-96.

Gong, M., S. Chen, Y. Song, and Z. Li. 1997. Effect of calcium and calmodulin on intrinsic heat tolerance in relation to antioxidant systems in maize seedlings. Aust. J. Plant Physiol. 24: 371-379.

Heckathorn, S.A., G.J. Poeller, J.S. Coleman, and R.L. Hallberg. 1996. Nitrogen availability alters the patterns of accumulation of heat stressinduced proteins in plants. Oecologia 105:413418.

Huang, B. and Q. Xu. 2000. Root growth and nutrient element status of creeping bentgrass cultivars differing in heat tolerance as influenced by supraoptimal shoot and root temperatures. J. Plant Nutr. 23:979-990.

Humble, G.D. and K. Raschke. 1971. Stomatal opening quantitatively related to potassium transport: Evidence from electron probe analysis. Plant Physiol. 48:447-453.

Jiang, Y. and B. Huang. 2001. Effects of calcium and antioxidant metabolism and water relations associated with heat tolerance in two coolseason grasses. J. Expt. Bot. 355:341-349.

Klein, J.D. and I.B. Ferguson. 1987. Effect of high temperature on calcium uptake by suspensioncultured pear fruit cells. Plant Physiol. 84:153156.

Lal, R. 1974. Soil temperature, soil moisture and maize yield from mulched and unmulched tropical soils. Plant Soil 40:129-143.

Larkindale, J. and M.R. Knight. 2002. Protection against heat stress-induced oxidative damage in Arabidopsis involves calcium, abscissic acid, ethylene, and salicylic acid. Plant Physiol. 128:682-695. 
Liu, H. 2008. Enhancing turfgrass nitrogen use under stresses, p. 557-604. In: Pessarakli, M. (ed.). Handbook of turfgrass management and physiology. CRC Press, New York, NY.

Liu, X. and B. Huang. 2005. Root physiological factors involved in cool-season grass response to high soil temperature. Environ. Exp. Bot. 53:233-245.

Marcum, K.B. 1998. Cell membrane thermostability and whole-plant heat tolerance of kentucky bluegrass. Crop Sci. 38:1214-1218.

Pan, X. and S. Liu. 2003. Effects of low-phosphorus stress on membrane lipid peroxidation and protective enzyme activities in leaves of different rice (Oryza sativa) cultivars. Rice Sci. 11:43-46.

Pellett, R.M. and E.C. Roberts. 1963. Effects of mineral nutrition on high temperature induced growth retardation of kentucky bluegrass. Agron. J. 55:474-476.
Rachmilevitch, S., M. DaCosta, and B. Huang. 2006. Physiological and biochemical indicators for stress tolerance. In: Huang, B. (ed.). Plantenvironment interactions. 3rd Ed. CRC Press, Boca Raton, FL.

Romani, A.M. and A. Scarpa. 2000. Regulation of cellular magnesium. Front. Biosci. 5:D720 D734.

Salisbury, F.B. and C.W. Ross. 1978. Plant physiology. 2nd Ed. Wadsworth Publishing Co., Belmont, CA.

Shaul, O. 2002. Magnesium transport and function in plants: The tip of the iceberg. Biometals 15:309-323.

Sherchand, K. and G.M. Paulsen. 1985. Response of wheat to foliar phosphorus treatments under field and high temperature regimes. J. Plant Nutr. 12:1171-1181.

Silman, N., M. Artman, and H. Engelberg. 1965. Effect of magnesium and spermine on the aggregation of bacterial and mammalian ribosomes. Biochim. Biophys. Acta 103:231-240.

Ticconi, C.A. and S. Abel. 2004. Short on phosphate: Plant surveillance and countermeasures. Trends Plant Sci. 9:548-555.

Turner, T.R. and N.W. Hummel. 1992. Nutritional requirements and fertilization, p. 407. In: Waddington, D.V., R.N. Carrow, and R.C. Shearman (eds.). Turfgrass. Agronomy Monograph 32. Agronomy Society of America, Madison, WI.

Wang, J. and R. Li. 1999. Changes of $\mathrm{Ca}^{2+}$ distribution in mesophyll cells of pepper under heat stress. Acta Horticulturae Sinica 26:5758.

White, P.J. and J.P. Hammond. 2008. The ecophysiology of plant-phosphorus interactions, p. 51-55. In: White, P.J. and J.P. Hammond (eds.). Phosphorus nutrition of terrestrial plants. Springer, Dordrecht, The Netherlands. 